NOTICIÁRIO

DESDOBRAMENTO DO CURSO DE GEOGRAFIA E HISTóRIA NA FACULDADE DE FILOSOFIA, CIENCIAS E LETRAS DA UNIVERSIDADE DE SÃO PAULO.

Em virtude da lei federal $n .^{\circ} 2.594$, de 8-IX-1955 ter desdobrado o Curso de Geografia e História das Faculdades de Filosofia em Curso de História e Curso de Geografia, baixou o Govêrno estadual o decreto $n .^{\circ} 25.701$, de 4-IV-1956, regulamentando a aplicação dessa lei na Faculdade de Filosofia, Ciências e Letras da Universidade de São Paulo. Esse decreto tem o seguinte teor:

Artigo 1. - 0 atual Curso de Geografia e História da Faculdade de Filosofia, Ciências e Letras da Universidade de São Paulo fica desdobrado em dois cursos independentes:

a) Curso de Geografia; b) Curso de História.

Artigo $20^{\circ}$ - 0 Curso de Geografia passa a ter a seguinte seriação de disciplinas:

$$
\text { 1a. Série }
$$

1. Geografia Física

2. Geografia Humana

3. Geografia do Brasil

4. Cartografia

5. Geologia

6. Antropologia

7. História da Civilização Moderna.

$$
\text { 2a. Série }
$$

1. Geografia Física

2. Geografia Humana

3. Geografia do Brasil

4. Geografia Regional

5. Cartografia

6. Etnografia Geral

7. História da Civilização Contemporânea.

3a. Série

1. Geografia Física

2. Geografia Humana

3. Geografia do Brasil

4. Geografia Regional

5. Botânica

6. Etnografia do Brasil e Noções de Tupi-Guarani

7. História da Civilização Brasileira.

Artigo $3 .^{\circ}$ - 0 Curso de História passa a ter a seguinte seriação de disciplinas:

$$
\text { 1a. Série }
$$

1. Introdução aos Estudos Históricos

2. História da Civilização Antiga

3. História da Civilização Medieval

4. Antropologia

5. Geografia. 
2a. Série

1. História da Civilização Moderna

2. História da Civilização Brasileira

3. História da Civilização Americana

4. Etnografia Geral

5. História da Civilização Ibérica

6. Disciplina Optativa.

3a. Série

1. História da Civilização Contemporânea

2. História da Civilização Brasileira

3. Histria da Civilização Americana

4. Etnografia do Brasil e Noçóes de Tupi-Guarani

5. Disciplina Optativa.

Artigo 4. Os alunos matriculados na segunda e terceira série do curso de História deverão escolher, obrigatòriamente, uma das disciplinas optativas fixadas cada ano pelo Conselho Técnico-Administrativo, por proposta do Departamento de História.

Artigo $50^{\circ}$ - As quartas séries dos cursos de Geografia e Hislória continuarão a ser regidas pela Lei Federal n. 9092, de 26 de marco de 1946.

Artigo $60^{\circ}$ - Será facultado aos atuais alunos do Curso de Geografia e História, matriculados sob o regime do Decreto n. 12.511 de 21 de janeiro de 1942 , optar pelo regime fixado no presente Decreto a critério do Conselho Técnico-Administrativo, conforme as conveniências do ensino.

$\S 10^{\circ}$ - A opção de que trata o presente artigo deverá ser efetuada antes da realização da 1a. prova parcial.

$\S 20^{\circ}$ - Os alunos que optarem pelo novo regime, nos têrmos do parágrafo anterior, ficarão obrigados aos novos "curricula" com as adaptações que se tornarem necessárias.

$\$ 3 .^{\circ}$ - Os alunos que optarem pelo novo regime e tiverem dependências de matérias, na época da opção, deverão satisfazê-las antes de receber o diploma do curso escolhido.

Artigo $7 .^{\circ}$ - Revogam-se as disposições em contrário.

$$
\begin{aligned}
& \text { JANIO QUADROS } \\
& \text { Vicente Paula Lima } \\
& \text { Alipio Corrêa Neto. } \\
& { }^{*}
\end{aligned}
$$

Quanto às matérias optativas da 2a. è 3a. série do Curso de História, êste ano foram oferecidas pelo Departamento de História as seguintes disciplinas:

História das Idéias Politicas; História da Filosofia; História Econômica; História da Educação; História da Literatura (inglêsa ou espanhola, alemã, francesa, latina, grega, portuguêsa e trasileira); História da Arte; Numismática; Paleografia.

$$
\text { E. SIMÕES DE PAULA }
$$

\section{CURSO DE NUMISMÁTICA.}

Este ano será ministrado na Faculdade de Filosofia, Ciências e Letras da Universidade de São Paulo um curso de Numismática pelo professor-visitante Dr. Slvaro da Veiga Coimbra, presidente da So- 